\title{
ПРЯМОЕ ГОСУДАРСТВЕННОЕ ФИНАНСИРОВАНИЕ ТЕКУЩЕЙ ДЕЯТЕЛЬНОСТИ ПОЛИТИЧЕСКИХ ПАРТИЙ В РОССИИ
}

\begin{abstract}
Аннотация: Настоящая статья посвящена изучению развития правового регулирования государственного финансирования политических партий, путем предоставления им государственных субсидий. Основное внимание было уделено анализуэффективностигосударственных расходовна поддержание сложивщейся партийной системы. Существующий сегодня порядок государственной поддержки партий не соответствует ни принципам разумности, ни объективности. Особенно данная проблема обострилась в последнее время в связи с тем, что Россия находится в экономически сложных условиях и существует острая необходимость оптимизации государственных расходов. Достоверность и обоснованность результатов, полученных в ходе исследования, достигается за счет применения системно-структурного, исторического, формально-юридического, метода анализа, толкования, лексическо-грамматического анализа, а также сравнительно-правового метода. На основе проведенного исследования сделаны выводы о необходимости реформирования системы государственного партийного финансирования. В связи с чем были предложень способы усовершенствования соответствующего законодательства. Прежде всего предлагается установить порядок определения объема выделяемых средств изгосударственного бюджета в виде определенного процента от его общего размера на соответствующий год, а также закрепить двухуровневую систему распределения государственных инвестиций между партиями. Подобные меры способствовали оптимизациигосударственных расходов, а также стимулировании развития политических партий, пользующихся наибольшей поддержкой населения страны.
\end{abstract}

Ключевые слова: Политические партии, госдуартвенное финансирование, текущая деятельность партий, текущее партийное финансирование, прямое государственное финансирование, оптимизация государственных расходов, государственные субсиди, партийная система, принцип разумности, госудратсвеньй бюджет.

Abstract: This article is dedicated to the examination of development of legal regulation of the government financing of political parties by means of granting state subsidies. A special attention is given to the analysis of the efficiency offederal spending aimed at support of the established party system. The currently existing order of government support of the political parties corresponds neither with the principles of reasonableness nor objectiveness. The severity of this issue has increased due to the fact that Russia is undergoing an economic crisis, thus there is an urgent need for optimization of state revenues. Based on the conducted research, the author concludes that there is a need for reform of the system of state party funding, and suggest the ways of improving the existing legislation. First and foremost, it is recommended to set the order of determining the volume of allocated funds from the federal budget in form of a certain percentage of its total size for the corresponding year, as well as establishing a dual-level system of disbursement of state investments among the parties. Such measures contributed into optimization of the federal spending, as well as encouraged the development of political parties that gain most support among the population of the country.

Keywords: Direct government funding, financing of political parties, current activity of political parties, government funding, political parties, optimization of federal spending, state subsidy, party system, principle of reseonableness, federal budget.

есмотря не неутихающие споры относительно обоснованности и целесообразности существования государственного финансирования политических партий, все же, как представляется, именно данный институт способен выступать в качестве наиболее эффективного метода и способа борьбы с политической коррупцией, нивелируя возможность влияния частных денег на принятие партиями политических решений. Однако при этом необходимо соответствие размера государственного субсидирования принципу разумности, не допуская таким образом «гиперфинансирования» и, как следствие, огосударствления партий. Наибольший интерес в этой связи представляет прямое государственное финансирование политических партий. В Российской Федерации государственное субсидирование имеет целью как цель покрытия затрат на избирательную кампанию, так и стимулирование, поддержание текущей деятельности партий. Согласно Федеральному закону «О политических партиях» государственные средства предоставляются политическим партиям лишь в двух следующих случаях:

1. Если федеральный список кандидатов, выдвинутый политической партией на выборах депутатов Государственной Думы Федерального Собрания Российской Федерации, получил по результатам выборов не менее 3 процентов голосов избирателей, принявших участие в голосовании по федеральному избирательному округу.

2. Если зарегистрированный кандидат на должность Президента Российской Федерации, вы- 


\section{Право и политика $12(192) \cdot 2015$}

двинутый политической партией, получил по результатам выборов не менее 3 процентов голосов избирателей, принявших участие в голосовании.

Установление законодателем 3\% барьер для получения государственного финансовой поддержки является некой гарантией достаточно широкой поддержки той или иной партии в обществе. Более того, дифференцированное финансирование политических партий получает по итогам голосования, помимо правовых оснований, социальную легитимацию [1, с.22]. Также государственное партийное финансирование может быть рассмотрено как поощрительный способ правового регулирования деятельности политических партий, - добившихся определенного успеха на выборах, направленный на стимулирование к политической активности в допустимых законом формах [2, с.27-28].

Прямое государственное финансирование, осуществляемом на основе результатов выборов депутатов Государственной Думы Федерального Собрания Российской Федерации представляет собой финансирование текущей деятельности партий. Об этом свидетельствует тот факт, что указанные средства предоставляются партиям ежегодно, следовательно, речь не идет о компенсации затрат на проведение избирательной кампании. Более того, данные средства предоставляются только по результатам выборов депутатов в Государственную думу России, что не позволяет рассматривать их как компенсацию понесенных затрат на избирательные кампании в законодательные органы субъектов, муниципальных образований и иные. При осуществлении государственного финансирования политических партий по результатам выборов Президента Российской Федерации, очевидно, что средства исключительно являются компенсацией затрат на предвыборную кампанию, так как выплачиваются единовременно. В настоящей работе основное внимание уделяется текущему государственному прямому финансированию политических партий, так как основное бремя для государственного бюджета связанно именно с данным видом оказания государственной партийной поддержки, что в сложившихся сегодня сложных экономических условиях требует более пристального внимания.

При изучении государственного партийного финансирования, важным для понимания сложившейся сегодня практики и системы осуществления государственной поддержки является рассмотрение изменений объемов бюджетного ассигнования в исторической перспективе. Впервые в Российской Федерации прямые государственные инвестиции были предус- мотрены в Федеральном законе от 11.07.2001 №95-Ф3 «О политических партиях». Согласно первоначальной редакции указанного закона политические партии, при выполнении требований закона, имели право получить государственное финансирование в размере не менее 0,005 минимального размера оплаты труда, установленного федеральным законом на 1 марта года, предшествующего году выделения этих средств, и умноженного на число избирателей, включенных в списки избирателей на ближайших предыдущих выборах депутатов Государственной Думы Федерального Собрания Российской Федерации либо выборах Президента Российской Федерации. Исходя из положений Федерального закона от 19.06.2000 №82 - Ф3 «О минимальном размере оплаты труда» минимальный размер оплаты труда был равен 100 рублям, следовательно, партия получала 50 копеек за каждого проголосовавшего за нее на соответствующих выборах. Данная норма просуществовала вплоть до 1 января 2006 года, когда в соответствии с Федеральным законом от 21.07.2005 № 93- Ф3 «О внесении изменений в законодательные акты Российской Федерации о выборах и референдумах и иные законодательные акты Российской Федерации» объем государственного финансирования был фактически увеличен в 10 раз и составил 5 рублей. Более того, важность указанных изменений заключалась еще и в том, что законодатель впервые зафиксировал точную сумму выплат, отказавшись от привязки к минимальному размеру оплаты труда. Федеральным законом «О внесении изменений в статьи 30 и 33 Федерального закона «О политических партиях» размеры государственного финансирования были увеличены еще в 4 раза и составили 20 рублей за один голос избирателя. Основанием для проведения последующих реформ, увеличения размеров государственных инвестиций до 50 рублей, называлась необходимость ограничить влияние частных инвесторов на деятельность политических партий.

Либерализация законодательства в области порядка создания новых политических партий привел к увеличению политической конкуренции в «борьбе за активы». В ноябре 2012 года Правительством Российской Федерации был предложен законопроект, согласно которому предусматривалось увеличение государственного финансирования политических партий, преодолевших указанный выше 3 \% барьер с 20 рублей за каждый полученный голос до 50 рублей. Внесенные изменения распространялись на политические партии, принявшие участие в выборах депутатов Государственной Думы Федерального Собрания Российской Федерации 6 созыва и получивших не менее $3 \%$ голосов. Сегодня 5 политических партий обладают правом на госу- 
дарственное финансирование, среди которых 4 парламентских партии и партия «Яблоко», получившая $3,43 \%$ голосов. Однако уже в октябре 2014 года в ст. 33 Федерального закона «О политических партиях» снова были внесены изменения, направленные на увеличение размера государственных субсидий до 110 рублей за каждый голос. Данная норма вступила в силу с 01 января 2015 года. Однако в сложных экономических условиях современной России, едва ли можно говорить о целесообразности внесения подобных поправок и о соответствии их принципу разумности.

Говоря о прозрачности финансирования политических партий, международное право исходит из необходимости соблюдения некого баланса между государственным финансированием партий и частными источниками формирования партийных бюджетов. Опасение в данной связи вызывает тот факт, что политические партии, финансовые средства которых более чем на половину формируются за счет государственных средств, едва ли могут рассматриваться как независимые общественные объединения при принятии ими своих политических решений.

Суммы, выделяемые из государственного бюджета России, являются довольно высокими и в сравнении с опытом зарубежных стран. Так, Польша в пересчете на российский рубль выделяет на финансирование политических партий около 543 млн. руб. [1], Австралия - 1,7 млрд. руб. [4], Канада - 826 млн. руб. [5], Великобритания - 435 млн. руб.[6]

Поддерживая предложение об увеличении размеров государственного субсидирования партий, Председатель Правительства Российской Федерации, Д.А. Медведев указывал, что подобные изменения позволят укрепить партийную систему и будут способствовать развитию демократии [7]. Подобная позиция представляется обоснованной, лишь при условии, что увеличение размеров такого финансирования будет отвечать принципу разумности. В условиях нестабильности экономики России, имеющей место сегодня, увеличение размера прямого государственного финансирования более чем в два раза, едва ли может рассматриваться как обоснованное и целесообразное. Основным же бенефициаром при этом остается «партия-власти», доходы которой во много раз выше, нежели у остальных политических партий, обладающих правом государственного субсидирования.

В 2012 году на финансирование пяти политических партий, которые смогли преодолеть $3 \%$ рубеж на выборах в государственную думу 6-ого созыва, было выделено, с учетом внесенных изменений, 4,5 млрд. рублей. По итогам выборов «Единая Россия» получила 49,32\% голосов, КПРФ - 19,19\%, ЛДПР -11,67\%,
«Справедливая Россия» - 13,24\%, «Яблоко» - 3,43\%, Патриоты России - 0, 97\%, «Правое дело»-0,60\%[18]. Таким образом, Единой России было перечислено за указанный отчетный период более половины выделенных из государственного бюджета средств на свое дальнейшее развитие. С января 2015 года, с учетом внесенных законодательных изменений, Единая Россия сможет рассчитывать на 5687 млн руб., КПРФ - 1960 млн руб., «Справедливая Россия» - 1084 млн руб., ЛДПР - 1049 млн руб., а «Яблоко» - 247 млн руб. Такая разница в полученных доходах от государства позволяет говорить о практической монополизации политического рынка.

В условиях сложившейся системы государственного финансирования политических партий в Российской Федерации, а также, учитывая необходимость оптимизации государственных расходов, видится разумным обратиться к опыту ряда стран и предусмотреть двухуровневую систему распределения бюджетных средств между политическими партиями, получившими право на государственное субсидирование. Более того, установление «привязки» размера государственных средств, выделяемых партиям, и количества голосов, полученных ими на ближайших предыдущих выборах депутатов Государственной Думы Российской Федерации, является спорным. С одной стороны, очевидно, что количество избирателей, проголосовавших за партию, является гарантом наличия в обществе широкой ее поддержки. С другой стороны, подобный подход не учитывает возможные изменения экономического положения страны, так как государство обязуется выплачивать фиксированный размер государственных средств из расчета полученного количества голосов.

Учитывая вышеизложенное, представляется более рациональным определять размер государственных отчислений политическим партиям, набравшим более 3\% голосов на предыдущих выборах депутатов Государственной Думы Российской Федерации, как процент от общего размера бюджета на каждый последующий год. Объем доходов в бюджет России за 2012 г. составил 11,780 трлн рублей. На финансирование текущей деятельности политических партий было выделено 4,5 млрд рублей, что составляет около $0,03 \%$. Подобный объем средств, затрачиваемый государством на поддержку политических партий, представляется достаточным. Таким образом, установив правило определения объема средств федерального бюджета позволит предоставлять необходимые средства для поддержания политической системы, а главное должной политической конкуренции, ограничивая 


\section{Право и политика $12(192) \cdot 2015$}

влияние частных доноров на партии. Более того, следует учитывать и тот факт, что во многом от решений политических партий, которые представлены в Государственной Думе, имеющих права на получение субсидирования, зависит уровень экономического развития государства. В случае увеличения размера федерального бюджета, политические партии могли бы рассчитывать на большие поступления со стороны государства. В случае же уменьшения - государство могло бы перераспределить денежные средства на более острые социальные нужды страны. Двухуровневая система распределения средств прямого государственного финансирования текущей деятельности политических партий в свою очередь позволила бы создать более справедливую систему государственного финансирования.

За 2014 год, Единая Россия получает государственные субсидии, размер которых в 23 раза превышает размер денежных средств, передаваемых политической партии «Яблоко», в 5,5 раз - ЛДПР, в 5 раз - Справедливой России и в 3 раза КПРФ. Подобный разрыв поступлений, как подчеркивалось выше, не допустим в условиях должной политической конкуренции.

Создание двухуровневой системы государственного финансирования партий видится необходимым в современных политических условиях, сложившихся в России, для обеспечения принципов демократии, плюрализма и равенства политических партий. Предусмотреть перераспределение 15\% от выделяемых Российской Федерацией средств между всеми политическими партиями, которые преодолели 3\% барьер на последних предыдущих выборах депутатов Государственной Думы Российской Федерации. Установление барьера в размере $3 \%$ голосов избирателей, полученных партиями на выборах депутатов Государственной Думы России, при преодолении которого последние приобретают право на государственное субсидирование, служит достаточным для подтверждения факт наличия широкой поддержки той или иной партии среди избирателей.

Эффективность деятельности политических партий и должное ее развитие в значительной мере зависит от доступа к финансовым ресурсам, возможности привлекать необходимый объем средств. В этой связи государственная поддержка направлена на недопущение «попадания» партий в зависимость от крупных доноров, иными словами на обеспечение их финансовой независимости при принятии тех или иных политических реше- ний. Перераспределение $15 \%$ от общего размера государственного финансирования деятельности партий позволило бы партиям, обладающим на то правом, получить доступ к достаточным финансовым ресурсам. Говоря о политических партиях, получивших право на государственное финансирование по результатам последних предыдущих выборах депутатов в Государственную Думу Российской Федерации, размер государственных субсидий для каждой из них составил бы около 138 млн. рублей.

Остальные выделяемые из федерального бюджета денежные средства, в размере $85 \%$ от общей суммы субсидий, предлагается распределять в соответствии с полученными процентами голосов на предыдущих выборах депутатов Государственной думы Российской Федерации. Таким образом, возможность получения более значительных финансовых ресурсов в зависимости от уровня поддержки избирателей, с одной стороны, соответствует необходимости партии, пользующейся более значительным доверием со стороны граждан на получения большего размера финансовой помощи, необходимой для осуществления своей деятельности. С другой стороны, при использовании данной модели разница между финансовыми поступлениями со стороны государства получаемыми партиями будет не столь велика. Если при существующей модели, как указывалось выше, размер государственного финансирования «Единой России»в 23 раза превышает такой размер финансирования партии «Яблоко», а ЛДПР - в 5,5 раз, то при предлагаемой модели данный разрыв сокращается до 7 и 3,5 раз соответственно. Более того такая модель государственного финансирования партий в большей степени соответствует международным стандартам осуществления государственной поддержки партиям и демократическим принципам.

Проведенный анализ правового регулирования государственного финансирования текущей деятельности политических партий в России показал необходимость существования института государственной поддержки партий. В отношении прямого финансирования политических партий со стороны государства, 3\% барьер для доступа к такому финансированию представляется достаточным и обоснованным, гарантирующим наличие значительной поддержки населения той или иной партии. Однако принципиально важным является то, что государственное финансирование, как прямое, так и косвенное должно осуществляться на принципах объективности и разумности. 
DOI: $10.7256 / 1811-9018.2015 .12 .17011$

При цитировании этой статьи сноска на dоі обязательна

Государственные институты и правовые системы

\section{Библиография:}

1. Романенко О.В. Государственное финансирование политических партий в России (проблемы правового регулирования) // Журнал о выборах. - 2001. - №1.

2. Братановский, С.Н., Развеев, Д.В. Административно-правовое регулирование организации и деятельности политических партий в Российской Федерации. - M.: Directmedia, 2014.

3. Evolutionally report on Italy Transparency of Party Funding (Theme II) Strasbourg/ 2012// http://www.coe.int

4. Australian Electoral Commission (2011). Election Funding and Disclosure. Report-Federal Election 2010

5. Public Financing of political parties. 01.03.2011//CBC News//www.cbenews.ca

6. Donation and public funds of political parties//www.electoralcommission.org.uk

7. Партиям повысили деньги в I чтении// Комерсантъ.215(5000) от 14.11.12.

\section{References (transliterated):}

1. Romanenko O.V. Gosudarstvennoe finansirovanie politicheskikh partii v Rossii (problemy pravovogo regulirovaniya) // Zhurnal o vyborakh. - 2001. - №1.

2. Bratanovskii, S.N., Razveev, D.V. Administrativno-pravovoe regulirovanie organizatsii i deyatel'nosti politicheskikh partii v Rossiiskoi Federatsii. - M.: Directmedia, 2014. 